\title{
Thermal Insulation Panel Based on Vegetable Typha Domingensis and Starch: Formulation and Physico-chemical Characterization
}

\author{
Henri Wilfried Hounkpatin 1, *, Victorin Kouamy Chégnimonhan ${ }^{2,3}$, Elisabeth Allognon-Houessou ${ }^{4}$, \\ Basile Bruno Kounouhewa ${ }^{1}$ \\ ${ }^{1}$ Laboratory of Radiation Physics (LPR), University of Abomey-Calavi, Cotonou, Benin \\ ${ }^{2}$ National Institute for Agronomic Research of Benin, CRA Agonkanmey, Cotonou, Benin \\ ${ }^{3}$ Thermics and Energy Laboratory of Nantes, University of Nantes, Nantes, France \\ ${ }^{4}$ Laboratory of Materials Thermophysical Characterization and Energy Appropriation (Labo- CTMAE/UAC), University of Abomey-Calavi, \\ Cotonou, Benin
}

Email address:

orestahenrius@gmail.com (H. W. Hounkpatin), victorin.chegnimonhan@univ-nantes.fr (V. K. Chégnimonhan), akoivieh@yahoo.fr (E. Allognon-Houessou), kbbasile@gmail.com (B. B. Kounouhewa)

${ }^{*}$ Corresponding author

\section{To cite this article:}

Henri Wilfried Hounkpatin, Victorin Kouamy Chégnimonhan, Elisabeth Allognon-Houessou, Basile Bruno Kounouhewa. Thermal Insulation Panel Based on Vegetable Typha Domingensis and Starch: Formulation and Physico-chemical Characterization. International Journal of Sustainable and Green Energy. Vol. 8, No. 2, 2020, pp. 29-37. doi: 10.11648/j.ijrse.20200902.12

Received: April 22, 2020; Accepted: May 14, 2020; Published: May 27, 2020

\begin{abstract}
The chemical characteristics of the typha-starch composite have been investigated in this study to optimize the component of the habitat insulation panel obtained from the two bio sourced materials. Four mixtures have been formulated and tested (starch $0 \mathrm{~g}$ + typha $620 \mathrm{~g}$; starch $62 \mathrm{~g}+$ typha $558 \mathrm{~g}$; starch $93 \mathrm{~g}+$ typha $527 \mathrm{~g}$; starch $124 \mathrm{~g}+$ typha $496 \mathrm{~g}$ ). The panels were made up of six different granulometries $(0.125 \mathrm{~mm} ; 0.250 \mathrm{~mm} ; 0.425 \mathrm{~mm} ; 1.25 \mathrm{~mm} 1.70 \mathrm{~mm} ; 3.15 \mathrm{~mm})$. A total of 72 panels were made and tested. The density of the panels varies from $515.6 \mathrm{~kg} \cdot \mathrm{m}^{-3}$ to $809.74 \mathrm{~kg} \cdot \mathrm{m}^{-3}$. Chemical characterisation reveals that typha particles contain a high content of organic matter and dry matter, as well as a significant proportion of water and volatile components. The typha which contains very little protein, little minerals and lipids, could contribute to the thermosetting during the manufacturing process of insulating panels. Formulations with low mass density such as L91 $(1.70 \mathrm{~mm}+124 \mathrm{~g} \mathrm{starch})$ and $\mathrm{G} 62$ (1.25 mm $+0 \mathrm{~g}$ starch) show good thermal properties according to literature.
\end{abstract}

Keywords: Typha-starch Composite, Bio Sourced Insulation, Chemical Properties, Green Building

\section{Introduction}

Improving energy efficiency in the building sector in West Africa is an important source of energy savings. Indeed, the building sector accounts for about $30 \%$ of electricity consumption in this region [1]. The good insulation of buildings reduces energy needs for improving thermal comfort. Research work has been oriented towards the use of eco-materials such as bio-based composites (hemp, straw, kenaf, flax etc.) as thermal insulation material because of their good environmental thermal performance. Thus, many works have addressed the levels of integration of these materials in the building envelope in order to provide answers to the need for indoor thermal comfort. In this approach, Hounkpatin et al. 2018a [2] have shown that straw roof insulation can reduce cooling requirements by $37 \%$ compared to conventional buildings that are in the form of a concrete slab. Hounkpatin et al. 2018b [3] in continuing previous work investigated the effect of thermal insulation of walls and ceilings with different thicknesses of straw bales. The authors obtained an average indoor temperature of $27^{\circ} \mathrm{C}$ within the extreme outdoor conditions $\left(32^{\circ} \mathrm{C}\right)$ of Benin 
without air conditioning. Krus et al. 2014 [4] proposed a magnesite-bound typha composite with extremely high strength and dynamic stability. With the typha panel as a filling for the wooden frames and as an additional inner insulation layer, an extremely thin outer wall construction with wall heating was realised. The conductivity of the entire building (infill construction and wood) is approx. 0.35 W. $\mathrm{m}^{-1} \mathrm{~K}^{-1}$. Diaw et al. 2018 [5] introduced $0.5 \%$ to $3 \%$ typha into the concrete and achieved a conductivity of 0.12 to 0.97 W. $\mathrm{m}^{-1} \mathrm{~K}^{-1}$. Niang et al. 2018 [6] studied the influence of the morphology and amount of typha on the hygrothermal behaviour of a typha-clay composite for building application. The results show a real impact of the type of typha fraction and its volume content on the hygrothermal properties of the studied material due to the porosity. Other authors such as Nenonone et al. (2014) [7] were interested in the chemical composition of certain bio-based materials (extracts of tanniferous organs of certain Togolese plants for the agglomeration of particles of kenaf stem (Hibiscus cannabinus L.). The authors considered that the presence of bio-adhesives such as tannins, proteins, fatty acids, etc. can make the manufacture of insulating panels thermosetting.

In Benin, these plant materials are encountered and some of them, such as typha, are even sources of pollution of water bodies. Their presence strongly disturbs socio-economic and environmental activities (health, water quality, agriculture, fishing, biodiversity) and causes quite a lot of harm to the inhabitants and operators of lake environments. To fight against the proliferation of typha and to clean up water bodies, lakes and lagoons, it is therefore essential to enhance the value of this plant by its exploitation in the habitat in order to ensure better natural thermal comfort. This work therefore resolves the harmful consequences of typha on the one hand and on the other hand, participates in the promotion of new local thermal insulation materials. To achieve this objective, the following measures have been taken:

1. Definition of a protocol for the manufacture of insulation panels;

2. Determining the density of composites, an important thermo physical characteristic;

3. Determining the chemical composition of typha particles and starch;

\section{Material and Methods}

\subsection{Material}

\subsubsection{Typha}

The typha stem is a monocotyledonous plant that grows in wetlands (lakes, lagoon, rivers, etc.). It is a species that belongs to the Tylphaceae family. In Benin, it is more likely to be found more in the regions of the Atlantic, Oueme-Plateau, and in the Mono-Couffo. Figure 1 gives an overview of the geographical situation in Benin of the regions in which this plant is located.

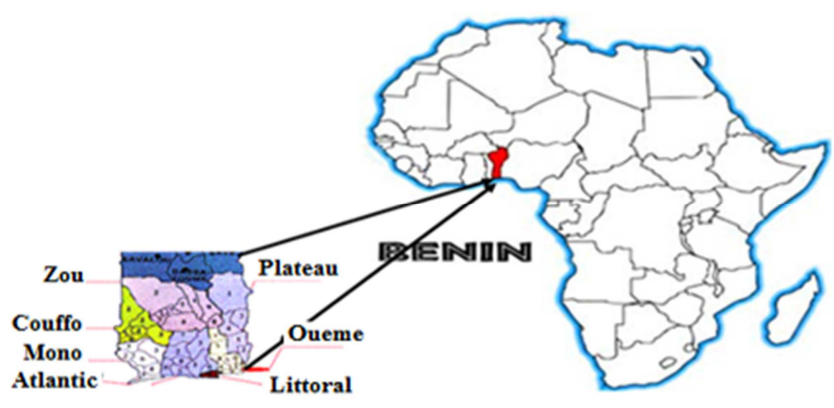

Figure 1. Geographical location in Benin of the Typha plant. Location in Africa.

Morphological characteristics such as leaf area, weight, leaf water content and nitrogen have a relevant positive relationship with an increase in leaf length. Random samples showed that $73 \%$ of the leaves of Norte Fluminense typha domingensis had a leaf length between 50 and $250 \mathrm{~cm} \mathrm{[8].} \mathrm{In}$ Benin, this plant has been used in the manufacture of traditional vegetable carpets or mattresses (locally called "Akôzan") for bedding for centuries [9]. In the case of this study, the stems are harvested in the Atlantic precisely in the Akogbato area. Figure 2 shows us the typha in its living environment.

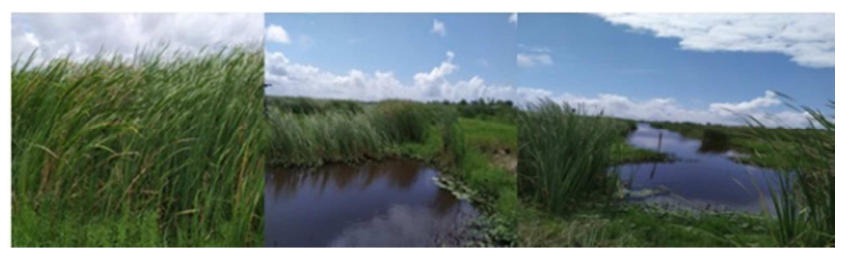

Figure 2. Typha domengensis image.

\subsubsection{Starch}

The starch of general formula $\left(\mathrm{C}_{6} \mathrm{H}_{10} \mathrm{O}_{5}\right)_{\mathrm{n}}$ is a binder of plant origin available in cities and countryside in Benin. It is extracted from cassava tubers, in the traditional way. It is often used as a binder in the food industry (Tapioca). However, its use as a binder in the manufacture of particle panels has not been discussed in the literature.

\subsubsection{Devices Used}

\section{(i) An Oven}

The oven allowed to dry the typha aggregates. It is GM brand, and was set at $105^{\circ} \mathrm{C}$ for 24 hours during testing as shown in Figure 3.

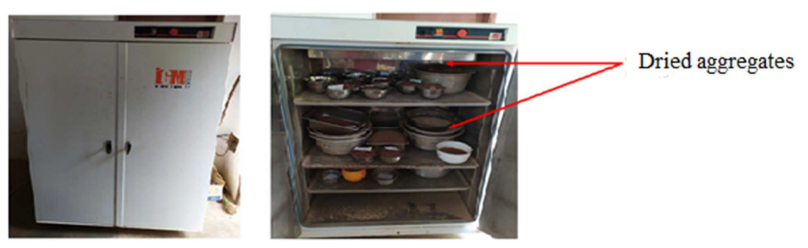

Figure 3. Front view of the oven.

\section{(ii) An Electronic Balance}

The electronic balance of Dawood brand as shown in Figure 4 gives a possibility of rapid weighing with an accuracy of 
$0.1 \mathrm{~g}$. It has a measurement range from $1 \mathrm{~g}$ to $3000 \mathrm{~g}$ allowing to define the proportion of reinforcement (typha) and binder for the formulation of the samples.

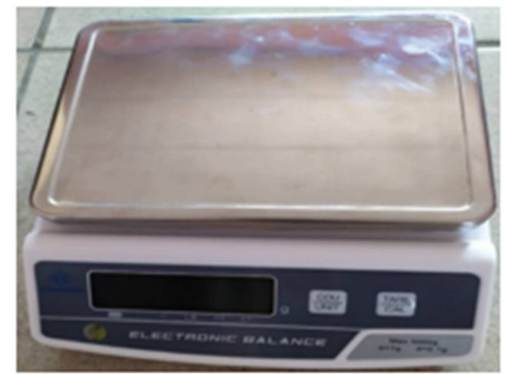

Figure 4. Photo of the precision balance (0.1g).

\section{(iii) A Mould}

In the case of this work, the mould used has the dimension $30 \mathrm{~cm} \times 30 \mathrm{~cm} \times 6 \mathrm{~cm}$ as shown in figure 5 .

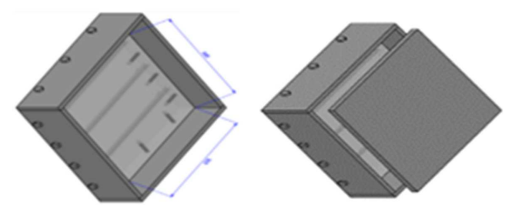

Figure 5. Photo of the mould.

\section{(iv) The Mixer}

The mixer of brand Hobart (Figure 6) is an electrical device with a variable speed. It facilitates the mixing of the typha particles and the starch.

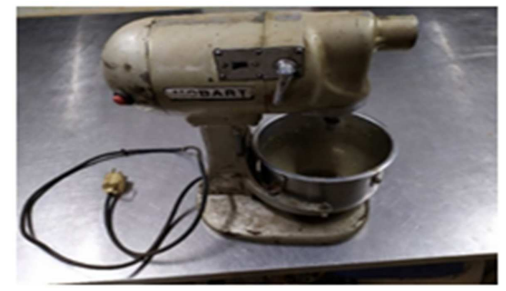

Figure 6. Photo of the mixer.

\section{(v) The Hydraulic Thermo-press}

The manual hydraulic thermo-press of the GM brand is a machine with a hydraulic circuit which provides high compressive force. The one used and illustrated in Figure 7 provides a force varying from 0 to $1500 \mathrm{KN}$, and allows the pressing of the particle panels.

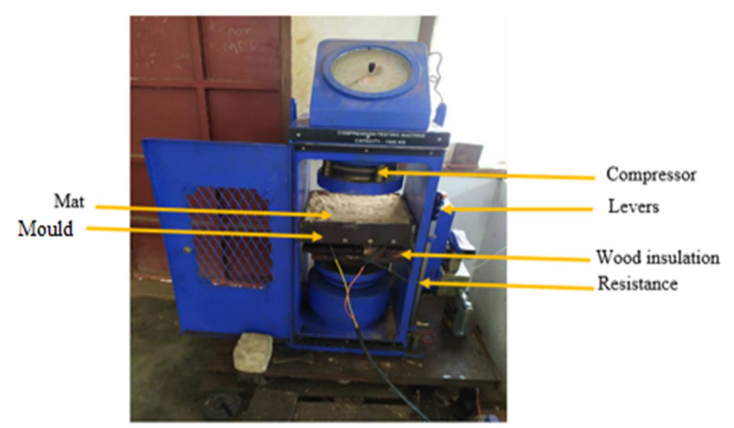

Figure 7. Photo of the GM hydraulic thermo-press.

\section{(vi) A Grinder}

A grinder mill (Figure 8) with a power of $0.75 \mathrm{KW}$, fitted with a $3.15 \mathrm{~mm}$ sieve to reduce the stalks of powdered typha to a size less than $3.15 \mathrm{~mm}$ has been used.

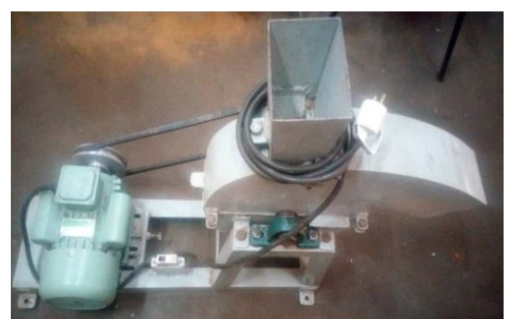

Figure 8. Photo of grinder mill.

\subsection{Methods}

The different methods used for the manufacture of typha-based insulation panels and its chemical characterisation are as follow.

\subsubsection{Method of Obtaining Insulation Panels from Typha}

The preparation (drying, grinding, sieving, thermo pressing) of insulation panel based on the typha was carried out at the Civil Engineering Laboratory (LGC) of the Polytechnic School of Abomey Calavi (EPAC) of the University of Abomey-Calavi in Benin.

\section{(i) Preparation of Particles}

Typha stems were harvested at maturity and dried for 2 weeks in the sun (Figure 9a). After drying, the stems are chopped into small aggregates with a size of approximately $1 \mathrm{~cm} \times 2 \mathrm{~cm}$ (Figure 9b). Then the aggregates are stored in an oven at a temperature of $105^{\circ} \mathrm{C}$ for 24 hours, then crushed into fine and medium particles using a knife grinder of Vicking type. The grinder is equipped with teeth which reduce the particles. The particles obtained have a size between 0.125 $\mathrm{mm}$ and $3.15 \mathrm{~mm}$.
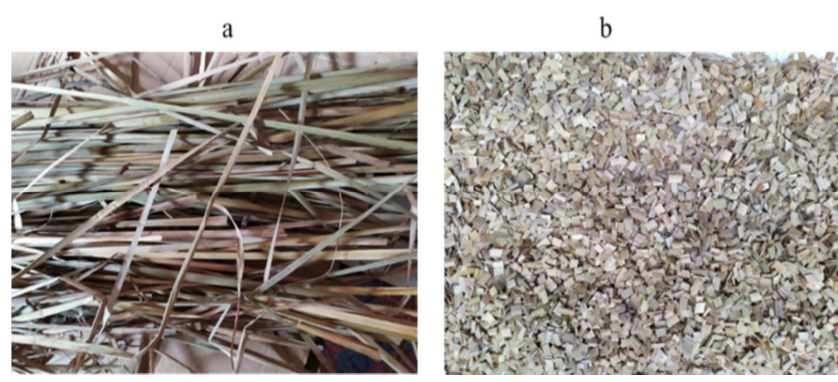

Figure 9. a) Dried typha stem b) chopped typha stem.

\section{(ii) Starch Powder Preparation}

The starch which will serve as a binder for the material, is dried in an oven $\left(70^{\circ} \mathrm{C}, 48 \mathrm{~h}\right)$ then is transformed into powder in a mill.

\section{(iii) Formulation of the Mixture Based on the Particles of Typha and Starch}

Typha stem particles (PTT) are mixed with starch powder and distilled water in a mixer of Hobart type for 15 minutes in 
order to obtain a homogeneous mixture of total mass $\mathrm{M}_{\mathrm{m}}$. For a good cohesion between the reinforcement (particle of typha) and the natural binder of vegetable origin (starch), it is provided a proportion of the binder of $0 \%, 10 \%, 15 \%$ and $20 \%$ to manufacture the panels of insulation. The rate of starch powder noted $\left(\mathrm{T}_{\mathrm{PA}}\right)$, introduced into the mixture is written:

$$
T_{P A}=\frac{M_{P A}}{M_{P A}+M_{T T}} \times 100
$$

With $M_{P A}$ : the mass of starch powder and $M_{T T}$ : the total mass of the particles of typha stems. The water content of the mixture $\left(H_{m}\right)$ is adjusted by adding a quantity of water defined as follows:

$$
H_{m}=\frac{M_{e}+\left[\left(M_{T T}+H_{T T}\right)+\left(M_{P A}+H_{\mathrm{PA})}\right)\right]}{M_{m}}
$$

With:

$$
M_{e}=M_{m} \times H_{m}-\left[\left(M_{T T} \times H_{T T}\right)+\left(M_{P A} \times H_{P A}\right)\right]
$$

$\mathrm{M}_{\mathrm{e}}$ : mass of water added in $(\mathrm{g}) ; M_{m}$ : total mass of the mixture in $(\mathrm{g}) ; H_{m}$ : humidity of the desired mixture; $M_{T T}$ : total mass of typha stem particles in $(\mathrm{g}) ; H_{T T}$ : Typha stem particle humidity $(14.83 \%) ; M_{P A}$ : mass of starch powder introduced in $(\mathrm{g})$; et $H_{P A}$ : humidity of the starch powder $(10.99 \%)$.

In Figure 10 an overview of the powdered starch and the typha particles is shown.

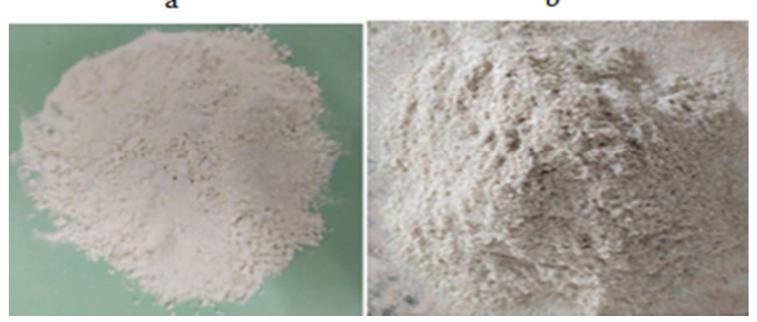

Figure 10. Photo of starch (a) and particles of typha (b).

\section{(iv) Particle Size Distribution}

The particle size distribution in accordance with standard " NF P 94-056 » allows to determine the different sizes of the aggregates which constitute the samples. To do this, the analysis consists in classifying the aggregates of typha particles, using a sieves series according to the sizes $0.125 \mathrm{~mm}$, $0.250 \mathrm{~mm}, 0.425 \mathrm{~mm}, 1.25 \mathrm{~mm}, 2 \mathrm{~mm}, 3.15 \mathrm{~mm}$. For this test, the mass of the particles $\mathrm{M}$ of typha stem is determined by the relation:

$$
\mathrm{D}_{\max }<\mathrm{M}<600 \mathrm{D}_{\max }
$$

$\mathrm{D}_{\max }$ : indicates the diameter of the sieve leaving all the particles past. In the present study, a mass of $950 \mathrm{~g}$ is taken, and previously dried in an oven to a constant mass with a maximum temperature of $105^{\circ} \mathrm{C}$ for 72 hours.

a) Principle of the test

The test consists to separate the aggregates constituting the sample through a sieves series fitted one on top of the other, the dimensions of the openings decreasing from top to bottom. The largest particles remain in the upper part of the highest sieves (refusal or retained) while the finest particles migrate to the lower sieves (sieving or passing). When the refusal on each sieve no longer varies, sieving ends, and all refusals are weighed.

\section{(v) Thermo Pressing of Particle Panels}

For the samples manufacture, a mould with a dimension of $30 \mathrm{~cm} \times 30 \mathrm{~cm} \times 6 \mathrm{~cm}$ has been designed and is provided with heating resistors. It controlled by a thermostat to regulate the interior temperature of the hotplate. After the mussel is placed between the heating plates of a hydraulic press from 0 to 1500 $\mathrm{KN}$. The mixture (reinforcement + starch) prepared is stacked and introduced into the mussel previously preheated to the constant temperature of $130^{\circ} \mathrm{C}$ defined for the thermo pressing. Two metal plates sliding inside the mussel allow to flatten the surfaces of the test piece. A constant pressure of $2.2 \mathrm{MPa}$ is applied for a necessary time of 20 minutes called pressing time to obtain the particle panel. After cooking the panel, it is removed from the mussel and left in the open air for 3 minutes, then immediately weighed and labeled. The mass and the cooking time are noted. It is then preserved in plastic packaging to limit the return of moisture.

\section{(vi) Density Measurement}

\section{b) Density of the raw material}

The density is determined by taking a mass $m_{\text {echm }}$ of 3 samples per raw material, then introduced into a graduated burette, with a compaction by shock (180 strokes/min for 5 minutes). After compacting, the reading of the volume $\mathrm{V}$ occupied by the material in the burette is carried out. The density $\rho$ of the burette is calculated as follows:

$$
\rho=\frac{m_{e c h m}}{V}
$$

c) Density of composites

The test consists of measuring the dimensions $(L \times l \times e)$ of a sample of particle panel in a test-tube, and deducing its volume $V_{e p r}$. By weighing the mass $m_{e p r}$ of the test-tube using an electronic balance of precision $0.1 \mathrm{~g}$, the density of the test-tube is calculated with equation (6):

$$
\rho_{e p r}=\frac{m_{e p r}}{V_{e p r}}
$$

\subsubsection{Chemical Composition of Plant Materials}

The chemical characterisation tests are carried out at the Laboratory of Physico-chemical Analysis of Aquatic Environments (LAPMIA) of the Faculty of Science and 
Technology (FAST) of the University of Abomey-Calavi.

\section{(i) Determination of the Dry Matter and Water as well as the Volatile Matter Content (AFNOR NF 94-050) [10]}

The dry matter and the water and volatile matter content were determined by the NREL method [11]. The contents were determined after drying the samples at $105^{\circ} \mathrm{C}$ for 24 hours. The empty crucibles are dried in an oven at $105^{\circ} \mathrm{C}$ for 30 minutes to an hour and then cooled in a desiccator for 20 minutes. Its dried crucibles are weighed empty.

A sample of $3 \mathrm{~g}$ has been taken in the crucibles and placed in an oven at $105^{\circ} \mathrm{C}$ for 24 hours. After 24 hours the crucibles containing the dry materials are weighed again. The dry matter content (MS) is determined using the following formula:

$$
\mathrm{MS}=\frac{\mathrm{M} 2-\mathrm{M} 0}{\mathrm{M} 1-\mathrm{M} 0}
$$

With M0 the mass of the crucible at the desiccator outlet, M1 the mass of the raw sample, M2 the constant mass.

The volatile matter water content (MEMV) is determined using the following formula:

$$
\mathrm{MEMV}=1-\mathrm{MS}=\frac{\mathrm{M} 1-\mathrm{M} 2}{\mathrm{M} 1-\mathrm{M} 0}
$$

\section{(ii) Determination of the Content of Mineral Matter and Organic Matter}

This involves determining the mineral and organic materials by weighing the ash obtained after drying a given quantity. The contents were determined by gravimetry after heat treatment of the samples in a muffle furnace. Five grams of sample are introduced into a previously tared capsule, and well distributed in a uniform, non-packed layer. The capsule is then placed for 6 hours (increasing phase for the first two hours and the remaining 4 hours to reach the plateau) in a muffle furnace (Nabertherm controller B180) at a temperature of $575^{\circ} \mathrm{C}$ according to the NREL method [12]. It is then cooled in a desiccator and then weighed with precision. The content of mineral matter Xm: for $100 \mathrm{~g}$ of sample and is calculated by the following formula:

$$
X m=\frac{G 2-G}{G 1-G} * 100
$$

Xm: Mineral content (\%), G: Mass of the empty crucible (g), G1: Mass of the crucible and the sample (g), G2: Mass of the crucible and white ash $(\mathrm{g})$.

The organic matter content Xo (\%) for $100 \mathrm{~g}$ of sample is calculated by the following formula:

$$
X o=\frac{G-G 2}{G-G 1} * 100
$$

\section{(iii) Determination of Fat Matter}

The fat matter is extracted according to the method of Folch et al. 1957 [13].

d) Principle of the method

The principle of the method of Folch et al. 1957 [13] is based on a solid-liquid cold extraction using two solvents: chloroform and methanol in the proportions 2: $1(2 \mathrm{~V}: 1 \mathrm{~V})$. Methanol participates in the breakdown of lipid-protein bonds while chloroform solubilizes the lipids. The addition of salt water $(0.58 \% \mathrm{NaCl})$ for washing makes it possible to remove the non-lipid substances from the mixture and to dissociate the acid lipids on the one hand. And on the other hand, it contributes to the separation of the chloroform phase (lower phase) containing lipids and methanolic phase (upper phase) containing hydrophilic substances (carbohydrates, proteins). The upper phase, consisting of methanol and water, contains hydrophilic compounds (carbohydrates and proteins), the dissolution of which is favoured by the presence of salt, while the lipids are dissolved in the lower chloroform phase [14]. The lower phase is recovered and evaporated until the total dry lipid extracts are obtained. The fat matter content is determined after weighing the lipids to dry.

e) Protocol

Five grams of sample were extracted with a mixture of 50 $\mathrm{ml}$ of chloroform (Sigma-Aldrich, ref. 650498) and methanol (Sigma-Aldrich, ref. 34860-1L-R) (2: 1, v/v), overnight under agitation. The whole has been filtered through a filter Whatman $\mathrm{N}^{\circ} 1$ and washed with the same mixture. The filtrate has been placed in a separation funnel and $20 \mathrm{ml}$ of Nacl at $0.58 \%$ were added, shook and left to settle. The chloroform phase was collected and filtered through $\mathrm{MgSO}_{4}$ in a previously weighed Büchi flask. It was evaporated to dryness at $35^{\circ} \mathrm{C}$ using a Büchi-type rotary evaporator and left vacuum packed for 15 minutes before the flask was weighed. The lipid content was determined by weighing the empty balloon and that containing the lipid residue after evaporation. The content of lipids $\mathrm{X}$ is calculated according to the following formula:

$$
X=\frac{(M b l-M b)}{M e c h} * 100
$$

With Mech: Mass of sample (g), Mb: Mass of the empty flask (g), Mbl: Mass of the balloon containing the lipid extract after evaporation of the solvent $(\mathrm{g})$.

\section{(iv) Determination of Raw Proteins}

\section{f) Principle}

The Kjedhal method was used to determine the protein content of the samples. It is carried out according to the following stages: mineralization, distillation and followed titration of the determination of the nitrogen content. The mineralization converts the organic nitrogen into mineral form. The mineral nitrogen is then distilled into ammonia and the released ammonia is dosed by acid-base assay. The standard conversion factor of 6.25 is used to convert the percentage of nitrogen to the percentage of protein.

g) Protocol

The method used follows the directive 93/28/EC (EEC, 1993) and is based on the Kjeldah method (Figure 11). The samples have been mineralized with sulfuric acid in the presence of a catalyst in the digestion system TECATOR 1015 The acid solution has then basified with sodium hydroxide, the released ammonia has distilled off and quantified by titration at sulfuric acid in a distiller (FOSS: Kjeltec 2300). The nitrogen content is determined. The percentage of protein is obtained by multiplying the percentage of nitrogen by the 
factor $6.25(100 \mathrm{~g}$ of protein $=16 \mathrm{~g}$ of nitrogen; $100 / 16=$ $6.25)$.

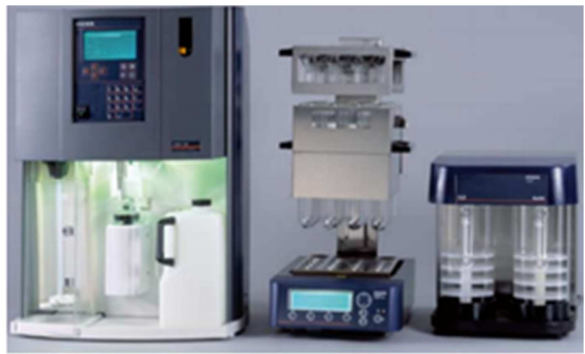

Figure 11. Kjedhal device (Kjeltec TM 2300 Analyzer Unit) for determination of raw proteins.

\section{Results and Discussion}

\subsection{Particle Size Analysis of the Typha and Formulation of the Mat (Typha Particle + Starch)}

The masses of the various retentions and passers-by are compared to the total mass of the material, which makes it possible to calculate their cumulative percentages (Table 1).

Table 1. Particle size distribution by sieving of the particles of typha stems.

\begin{tabular}{lllll}
\hline $\begin{array}{l}\text { Sieve } \\
(\mathbf{m m})\end{array}$ & $\begin{array}{l}\text { Partial } \\
\text { refusal } \mathbf{( g )}\end{array}$ & $\begin{array}{l}\text { Mass of } \\
\text { cumulative } \\
\text { refusals } \mathbf{( g )}\end{array}$ & $\begin{array}{l}\text { Percentage of } \\
\text { cumulative } \\
\text { refusals (\%) }\end{array}$ & $\begin{array}{l}\text { Percentage } \\
\text { of sieves } \mathbf{( \% )}\end{array}$ \\
\hline 4 & 0 & 0 & 0 & 100 \\
3.15 & 39.8 & 39.8 & 4.19 & 95.81 \\
2 & 86.9 & 126.7 & 13.34 & 86.66 \\
1.25 & 111.7 & 238.4 & 25.09 & 74.91 \\
0.425 & 449.6 & 688 & 72.41 & 27.59 \\
0.250 & 151.5 & 839.5 & 88.37 & 11.63 \\
0.125 & 110.4 & 949.9 & 99.99 & 0.01 \\
Total & 949.9 & - & - & - \\
\hline
\end{tabular}

The variation of the percentages of the sieves according to the particles size is presented in Figure 12.

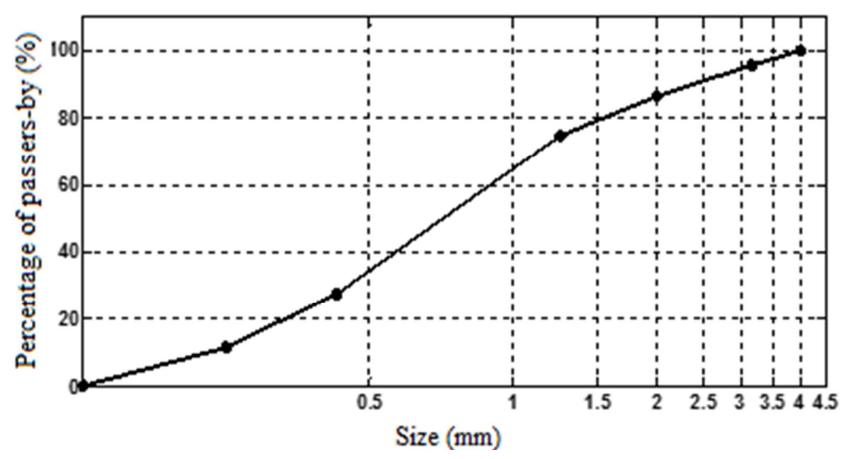

Figure 12. Particle size analysis by sieving the typha particles.

The interpretation of the particle size distribution in percentages of the total mass obtained by sieving allows to classify the particles into three classes, for the production of panels.

a) Class A: fine particles $\in([0.125 ; 0.425 \mathrm{~mm}])$

b) Class B: particles of intermediate size $\in$ (] 0.425; $1.25 \mathrm{~mm}])$ c) Class C: large particles $\in(] 1.25 ; 3.15 \mathrm{~mm}])$

The particles most used in the manufacture of insulation panels have a particle size which varies between $0.063 \mathrm{~mm}$ and $2 \mathrm{~mm}$ [15]. In the case of this study, four mixtures (Starch + Typha Particles) were formulated in the following proportions for the production of three samples by particle size $(0.125 \mathrm{~mm}$, $0.250 \mathrm{~mm}, 0.425 \mathrm{~mm}, 1.25 \mathrm{~mm}, 1.70 \mathrm{~mm}, 3.15 \mathrm{~mm}$ ) using the electronic balance:

\section{$\{$ Starch $0 \mathrm{~g}(0 \%$ of the total mass $)$ \\ Reinforcement $620 \mathrm{~g}$ (100\% of the total mass)}

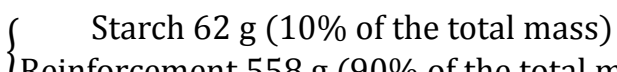

Reinforcement $558 \mathrm{~g}$ (90\% of the total mass)

$\left\{\begin{array}{c}\text { Starch } 93 \mathrm{~g}(15 \% \text { of the total mass) } \\ \text { Reinforcement } 527 \mathrm{~g} \text { (85\% of the total mass) }\end{array}\right.$

$\int$ Starch $124 \mathrm{~g}$ (20\% of the total mass)

Reinforcement $496 \mathrm{~g}$ (80\% of the total mass)

A total of seventy-two samples are made. The experience has shown that panels made from $0.125 \mathrm{~mm}$ aggregate sizes undergo bursting and delamination as a result of sudden pressure relief when the opening of the mussel.

To determine the density of composites, six samples could be tested: the particle sizes $(0.425 \mathrm{~mm}, 1.25 \mathrm{~mm}, 1.70 \mathrm{~mm})$ with two types of mixtures (Starch $0 \mathrm{~g}(0 \%$ the total mass) and Starch $124 \mathrm{~g}(20 \%$ of the total mass)). The following formulations were therefore made for the mixture typha + starch:

$$
\begin{aligned}
& 0.425 \mathrm{~mm}\left\{\begin{array}{c}
20 \%\left(\mathrm{M}_{71}\right) \\
0 \%\left(\mathrm{G}_{22}\right)
\end{array} ;\right. \\
& 1.25 \mathrm{~mm}\left\{\begin{array}{c}
20 \%\left(\mathrm{M}_{91}\right) \\
0 \%\left(\mathrm{G}_{62}\right)
\end{array}\right. \\
& 1.70 \mathrm{~mm}\left\{\begin{array}{c}
20 \%\left(\mathrm{~L}_{91}\right) \\
0 \%\left(\mathrm{G}_{31}\right)
\end{array}\right.
\end{aligned}
$$

Figure 13 shows piles of manufactured panels.
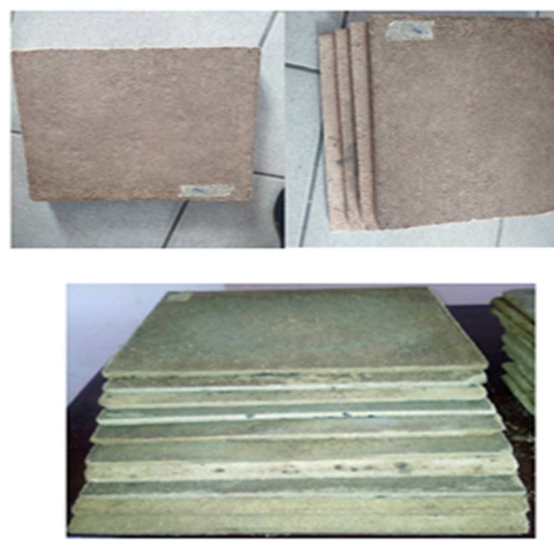

Figure 13. Thermo-compressed particle panels.

\subsection{Variation of Typha and Starch Density}

Figure 14 shows the variation of the raw material density (typha and starch). 

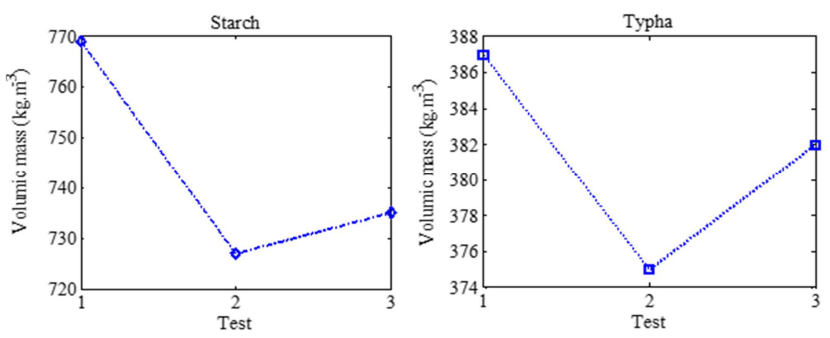

Figure 14. Density of starch and typha.

Three tests were performed to determine the density of typha and starch. The values observed indicate that starch is denser than typha. The average density is estimated at 735 $\mathrm{kg} . \mathrm{m}^{-3}$ for starch and $382 \mathrm{~kg} \cdot \mathrm{m}^{-3}$ for typha. In the studies of Chen et al. 2010, the authors consider that the ceiling panels at low density $\left(<500 \mathrm{~kg} \cdot \mathrm{m}^{-3}\right)$ have better thermal insulation properties compared to medium density panels. The typha that responds these requirements could therefore be a good candidate for improving energy efficiency of the buildings as an insulating material.

Figure 15 displays the variation of the composites density according to the binder rate and the granulometry. It can be noticed that the composites density at $20 \%$ starch is a decreasing function of the granulometry. This finding is not fully verified at the level of samples without binder. It is noted on this material type that the density does not always depend on the particle size type. The highest densities are observed for the composite at $20 \%$ starch. The highest value is evaluated at $809.74 \mathrm{~kg} . \mathrm{m}^{-3}$ for the sample M71 (particle size $0.425 \mathrm{~mm}$ with $20 \%$ starch) and the lowest value is estimated at 515.6 kg. $\mathrm{m}^{-3}$ and represents sample G62 (particle size $1.25 \mathrm{~mm}$ with $0 \%$ starch). Niang et al. 2018 evaluated the density of three composite formulations (clay + typha). The density of the samples varies from $323 \mathrm{~kg} \cdot \mathrm{m}^{-3}$ to $586 \mathrm{~kg} \cdot \mathrm{m}^{-3}$ and are close to certain values of the formulations of the current study.

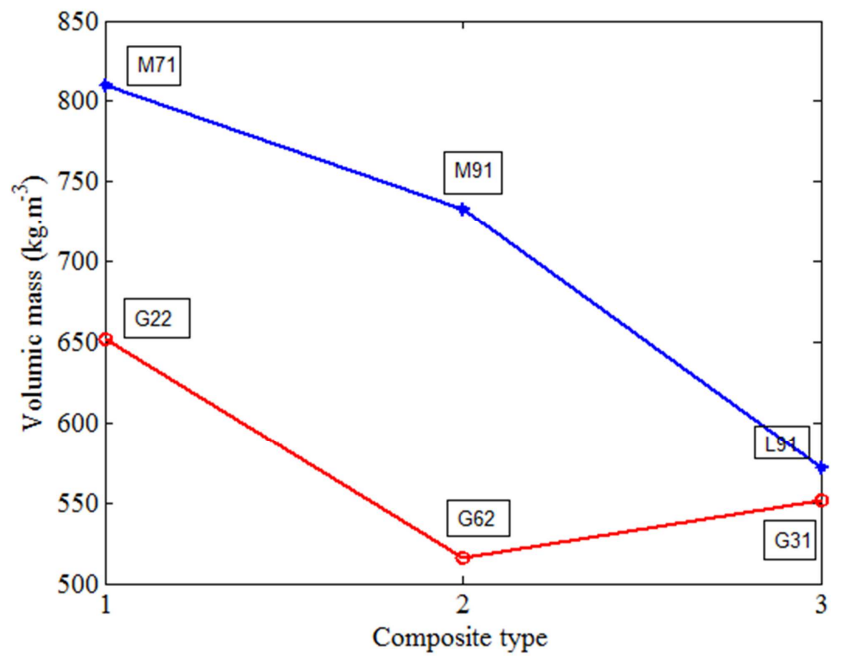

Figure 15. Variation of the composites density.

\subsection{Chemical Characterisation of the Typha Panels}

The lipid, protein, dry matter, water, volatile, mineral and organic matter contents of the mixture studied are presented in Table 2.

Table 2. Chemical composition of the typha panels and starch.

\begin{tabular}{|c|c|c|c|c|c|c|c|}
\hline Test & 1 & 2 & 3 & 4 & average & standard deviation & Result \\
\hline \multicolumn{8}{|l|}{ Lipid (\%) } \\
\hline Starch & 0.022 & 0.02 & 0.024 & & 0.022 & 0.001 & $0.022 \pm 0.001$ \\
\hline Typha particle & 0.32 & 0.32 & 0.28 & & 0.307 & 0.018 & $0.307 \pm 0.018$ \\
\hline \multicolumn{8}{|l|}{ Protein (\%) } \\
\hline Starch & 0.26 & 0.21 & 0.2 & 0.190 & 0.215 & 0.026 & $0.215 \pm 0.026$ \\
\hline $\begin{array}{l}\text { Typha particle } \\
\text { dry matter (\%) }\end{array}$ & 3.29 & 3.26 & 3.16 & 3.220 & 3.2325 & 0.048 & $3.232 \pm 0.048$ \\
\hline Starch & 89.12 & 89 & 88.91 & & 89.010 & 0.086 & $89.010 \pm 0.086$ \\
\hline Typha particle & 85.13 & 85.22 & 85.16 & & 85.170 & 0.037 & $85.170 \pm 0.037$ \\
\hline \multicolumn{8}{|c|}{ Water and volatile matter content $(\%)$} \\
\hline Starch & 10.88 & 11 & 11.09 & & 10.990 & 0.086 & $10.990 \pm 0.086$ \\
\hline Typha particle & 14.87 & 14.78 & 14.84 & & 14.830 & 0.037 & $17.830 \pm 0.037$ \\
\hline \multicolumn{8}{|c|}{ Mineral content $(\%)$} \\
\hline Starch & 0.96 & 0.99 & 1 & & 0.983 & 0.016 & $0.983 \pm 0.016$ \\
\hline Typha particle & 1.62 & 1.53 & 1.74 & & 1.630 & 0.086 & $1.630 \pm 0.086$ \\
\hline \multicolumn{8}{|c|}{ Organic content (\%) } \\
\hline Starch & 99.04 & 99.01 & 99 & & 99.017 & 0.016 & $99.017 \pm 0.016$ \\
\hline Typha particle & 98.38 & 98.47 & 98.26 & & 98.370 & 0.086 & $98.370 \pm 0.086$ \\
\hline
\end{tabular}

In Table 2 the typha particles contain a large content of organic matter and dry matter respectively evaluated to $(98.370 \pm 0.086) \%$ and $(85.170 \pm 0.037) \%$. The water and volatile matter content evaluated to $(17.830 \pm 0.037) \%$ indicates that the typha particles contain a significant proportion of these constituents. As for the contents in mineral matter, protein and lipid, the results show that the typha contains very little protein and even less minerals and lipid whose proportions are respectively evaluated to $(3,232 \pm$ $0.048 ; 1,630 \pm 0.086 ; 0.307 \pm 0.018) \%$. The starch used as a binder in the mixture contains a little more organic matter $(99.017 \pm 0.016) \%$, more dry matter $(89.010 \pm 0.086) \%$, less water and volatile matter $(10.990 \pm 0.086) \%$, less minerals, lipid and protein respectively evaluated at $(0.983 \pm 0.016$; $0.022 \pm 0.001 ; 0.215 \pm 0.026) \%$ compared to the typha particles. In the studies of Nenonene et al. 2014, the authors 
estimated that in order to produce particle panels respectful to the human health and the environment, research has increasingly focused on partial or total substitution of the conventional synthetic resins containing formaldehyde by bio adhesives such as tannins, proteins, fatty acids, etc. The presence of the chemical compositions contained in the typha particles could therefore show their effectiveness as a thermosetting matrix in the manufacture of the insulation panels.

In sum, the results obtained in this study proved that the combination of typha and starch stems is suitable for the manufacture of thermosetting insulation panels based on the typha-starch composite. Formulations with low mass density such as L91 and G62 could therefore present better thermal properties based on the work of Chen et al (2010). The valorisation of this local plant as an innovative thermal insulation material in buildings is thus an advantage to fight against water pollution in Benin, as well as to ensure thermal comfort while reducing energy bills and the environmental impact of hyper-processed industrial insulation such as polystyrene.

\section{Conclusion}

The manufacture protocol of the insulation panels based on typha-starch composite and their chemical characteristics were approached in this study in order to enhance this plant for improvement of the thermal comfort in buildings. The different stages of the typha insulation panels preparation were presented with the granulometry used and chemical characteristics such as water, volatile, dry matter, mineral, organic and protein content have been determined. The results obtained can be summarized as follows:

1) From the vegetable typha and starch, 72 samples of thermal insulation panels with the particle sizes $(0.125$ $\mathrm{mm} ; 0.250 \mathrm{~mm} ; 0.425 \mathrm{~mm} ; 1.25 \mathrm{~mm} 1.70 \mathrm{~mm} ; 3.15 \mathrm{~mm}$ ) have been prepared.

2) For the particle size of $0.425 \mathrm{~mm} ; 1.25 \mathrm{~mm}$ and $1.70 \mathrm{~mm}$ with starch $0 \mathrm{~g}$ ( $0 \%$ of the total mass) and starch $124 \mathrm{~g}$ ( $20 \%$ of the total mass)), the density of the composites varies from $515.6 \mathrm{~kg} \cdot \mathrm{m}^{-3}$ to $809.74 \mathrm{~kg} \cdot \mathrm{m}^{-3}$.

3) The chemical characterisation reveals that the typha particles contain a high content of organic matter and dry matter respectively evaluated to $(98.370 \pm 0.086) \%$ and $(85.170 \pm 0.037) \%$. They contain a significant proportion of water and volatile matter evaluated to $(17.830 \pm 0.037) \%$ and contains a very little protein and even less minerals and lipid, the proportions of which are respectively evaluated to $(3.232 \pm$ $0.048 ; 1.630 \pm 0.086 ; 0.307 \pm 0.018) \%$. The presence of these different levels of chemical composition in the particles of typha could therefore show their effectiveness as a thermosetting matrix in the manufacture of insulation panels, such as showed the studies of Soulama 2014 [17].

In view of these results, the use of this local plant as an innovative thermal insulation material in buildings therefore has undeniable ecological advantages. Formulations with a low mass density such as L91 and G62 could therefore have better thermal properties.

\section{Acknowledgements}

We would like to thank DALOHOUN Kouessi Joachim for his help in the determining of the typha and starch chemical compositions at the Laboratory of Physico-chemical Analysis of Aquatic Environments (LAPMIA) of the University of Abomey-Calavi, Benin.

\section{References}

[1] G. O. S. Omolola, "Thermomechanical formulation and characterisation of mortars reinforced with banana trunk fibers". Ph.D. Thesis, Université d'Abomey-Calavi, 2017.

[2] H. W. Hounkpatin, G. C., Sèmassou, B. Kounouhewa, E. Sanya, A. Vianou, "Study of the impact of thermal inputs by roofs on the hygrothermal comfort of habitats in tropical environment", International Journal of Current Research, 2018a, Vol. 10, Issue, 08, pp. 72323-72336.

[3] H. W. Hounkpatin, B. Kounouhewa, K. V. Chégnimonhan, C. Sèmassou and A. Vianou, "Numerical Investigation of the Effects of Insulated Envelopes on Hygrothermal Comfort within Habitats of Southern Benin: Test of a Local Material", Current Journal of Applied Science and Technology, 2018b, vol 31, nº, pp. 1-19.

[4] M. Krus, W. Theuerkorn, T. Großkinsky, H. Künzel. "New sustainable and insulating building material made of cattail. 10th Nordic Symposium on Building Physics", 15-19 June 2014, Lund, Sweden, pp. 1252-1260.

[5] A. S. Diaw, H. B. Bal, M. Wade, S. Gaye "Use of Typha Australis in the Habitat for the Improvement of Energy Efficiency of Buildings", Journal of Scientific and Engineering Research, 2018, vol 5, $\mathrm{n}^{\circ} 1$, pp. 164-171.

[6] I. Niang, C. Maalouf, T. Moussa, C. Bliard, E. Samin, C. Thomachot-Schneider, M. Lachi, H. Pron, T. H. Mai and S. Gaye "Hygrothermal performance of various Typha-clay composite, Journal of Building Physics, 2018, pp. 1-20.

[7] A. Y. Nenonene, K. Koba, K. Sanda, L. Rigal "Composition chimique et propriétés adhésives d'extraits d'organes tannifères de quelques plantes du Togo pour l'agglomération de particules de tige de kénaf (Hibiscus cannabinus L.), J. Soc. Ouest-Afr. Chim, 2014, vol 37, pp. 49-55.

[8] B. S. Esteves., A. Enrich-Prast and M. S. Suzuki, "Allometric relations for Typha domingensis natural populations". Acta limnol. Bras., 2008, vol. 20, nº. 4, p. p 305-311.

[9] J. Odjoubere. "Pressions anthropiques sur les milieux humides dans le sud du Benin. Revue de géographie du laboratoire leïdi", 2016, vol 15, 184-199.

[10] AFNOR (Association Française de Normalisation). Sols: reconnaissance et essais de détermination de la teneur en eau pondérale des matériaux par étuvage. NF P 94-050. 1995

[11] L. Ehrman (1994) "Book review. The Genome of Drosophila melanogaster", J. Hered, 1994, vol 85, n6. 495.

[12] A. Sluiter, R. Ruiz, C. Scarlata, J. Sluiter, and D. Templeton, "Determination of Extractives in Biomass". Laboratory Analytical Procedure (LAP). Issue Date: 7/17/2005. 
[13] J. Folch, M. Lees, G. H. S. Stanley, A simple method for the isolation and purification of total lipides from animal tissues, The Journal of Biological Chemistry, 1957, vol 226, pp. 497509 .

[14] J. Dumay, "Extraction de lipides en voie aqueuse par bioréacteur enzymatique combiné à l'ultrafiltration: application à la valorisation de co-produits de poisson (Sardina pilchardus)", Thèse de doctorat de l'université de Nantes, France 2006.

[15] A. Y. Nenonene, "Elaboration et caractérisation mécanique de panneaux de particules de tige de kénaf et de bioadhésifs à base de colle d'os, de tannin ou de mucilage", Thèse de doctorat, Université de Toulouse, France, 2009.
[16] D. Chen, J. Li and J. Ren, "Study on sound absorption property of ramie fiber reinforced poly (L-lactic acid) composites: Morphology and properties. Composite. Part A", Applied Science Manufacture, 2010, vol 41, n 8 , pp. 1012-1023.

[17] S. Soulama, "Caractérisation mécanique et thermique de biocomposites à matrice polystyrène recyclé renforcée par des coques de cotonnier (Gossypium hirsutum L.), ou de particules de bois de kénaf (Hibiscus Cannabinus L.)". Thèse Sciences pour l'ingénieur (Génie Mécanique). Belfort - Montbéliard: Université de Technologie de Belfort - Montbéliard, 2014. 